\title{
Autonomous and/or Institutionalized Social Movements? Conceptual Clarification and Illustrative Cases.
}

Hans Pruijt - Erasmus Universiteit Rotterdam, Department of Social Sciences, Sociology, PO Box 1738, 3000 DR Rotterdam, pruijt@ fsw.eur.nl

Conny Roggeband, FLACSO Ecuador, Departamento de Estudios Politicos, cmroggeband@flacso.edu.ec

The final, definitive version of this paper will be published in International Journal of Comparative Sociology 55/2, April 2014, pp. 144 - 165, by SAGE Publications Ltd, All rights reserved. (C) Hans Pruijt, Conny Roggeband.

\section{Abstract}

Case studies of urban squatting in the United States and the Netherlands, and the fight against sexual violence in Spain and in the Netherlands form the empirical basis of an analysis of the features and development of autonomous and institutionalized social movements, and the interaction between them. Autonomous and institutionalized social movements have different strengths that they derive from characteristics that are not compatible. Nevertheless, a dynamic is possible that combines the strengths of both models. It provides synergy between selfcontained autonomous and institutionalized movements, without imposing trade-offs. Political opportunity theory suggests that such a "dual-movement structure" is most relevant when the political system is selectively open. Interaction between the movements is conditioned by the mainstreaming potential of the issue or interest that is at stake.

Even when relations are tense, movements can create opportunities for each other. Autonomous movements are able to retain a repertoire of disruptive actions when lobbying is the more popular option. An autonomous movement can benefit from the legitimacy and supporting network engendered by an institutionalized movement, pioneering work done by an autonomous movement can inspire an institutionalized counterpart. Autonomous movements can provide a critical voice when co-optation occurs.

\section{Introduction}

Social movements formed to affect social justice and change differ in terms of whether their orientation is predominantly autonomous - such as the Occupy movement - or institutionalized, such as the civil rights movement. An autonomous orientation entails emphasizing self-management, egalitarian, nonhierarchical structures, and consensus-based decision making. Ends and means have a continuity that reflects activists' attempts to apply their ideas of an ideal society to their own movement. In contrast, an institutionalized orientation is characterized by a clear division of labor and authority, a centralized organization, and a loose coupling of ends and means. 
The autonomous and institutionalized models have different strengths. In the autonomous model, movements are free from the constraints of representative politics (Katsafiacas 1997), are able to trigger institutional disruption to defy the elite (Piven and Cloward 1977), and can mobilize without having to command large resources. New social movement theory suggests a further advantage: The autonomous model is attractive to those who share post-materialist values (Offe 1985), especially a growing section of the middle class, the "social and cultural specialists" (Kriesi et al. 1995). Participants can be active without a fixed commitment (Tarrow 1994). In contrast, the strengths of the institutionalized model include good prospects for sustained relationships with allies and supporters, low risk of dispersion of power, cohesion, and a relatively good ability to contain repression (Tarrow 1994). In this paper, we explore the idea that a dynamic that combines the strengths of both models is theoretically possible. Combining the strengths of both models implies overcoming a tradeoff problem because the strengths of the institutionalized model presuppose control, hierarchy and bureaucracy, while the strengths of the autonomous model presuppose the opposite features. Existing research shows that such a trade-off can lead to a dilemma that can be detrimental to a social movement or a social movement organization (SMO). Breines (1980) describes how the American New Left Movement of the 1960s was unable to solve the dilemma between building up organizational power and engaging in "prefigurative politics", i.e. shaping the movement along the lines of the desired society. Staggenborg (1989) notes that there is a tradeoff of innovation and stability that is difficult to avoid: stability is best served by a formalized organization, and innovation by an organization that is less-formalized, and suggests that success is likely to come from a combination that contains separate organizations that are either clearly formalized or clearly less-formalized. This can be seen as an example of a general theoretical solution for trade-off problems caused by incompatibilities: differentiation into optimized subsystems with contrasting features (cf. Scott and Davis 2007, 76-79).

Following this logic, our analysis focuses on the interaction between selfcontained entities that have pronounced characteristics that place them on either side of the autonomous - institutionalized spectrum. Taking a comparative approach, we explore this dual movement structure with the aim to shed light on the context-dependent mechanisms that are involved in its emergence and on synergistic dynamics.

The analysis yields three theoretical results:

1. A rebuttal of the idea that as a result of cultural change, autonomous "new social movements" have superseded movements that have more institutional characteristics, making them obsolete.

2. A demonstration of the value of moving beyond the movement level to a higher level of inclusiveness - analogous to organizational field level analysis (Scott and Davis 2007) - to bring synergistic mechanisms to light.

3. Opening space to analyze synergistic effects beyond the familiar "radical flank effect" (Koopmans 2007, 27), that is, the possibility that pressure from a movement's radical wing enables the moderate wing to push demands. For this reason, we attempt a clear analytical separation between the autonomous vs. institutionalized and the radical vs. moderate dimensions.

First, this paper provides some conceptual clarification. Then, we address the opportunities based framework that forms the theoretical starting point for our explorations, before introducing the case studies - urban squatting in the Netherlands and in the US, and the fight against sexual violence in the Netherlands and Spain. We also discuss the selection of these cases. 


\section{Conceptual clarification}

Table 1 summarizes the common characteristics of the autonomous and institutionalized models. In the autonomous model, self-management is both internal and external, and alignment with external actors such as political parties is not accepted. However, the autonomous model does not exclude embarking on institutional actions, such as making demands to the state, using the legal system, seeking help from political parties, or accepting subsidies.

Table 1. The autonomous and institutionalized models

\begin{tabular}{|l|l|}
\hline \multicolumn{1}{|c|}{ Autonomous Model } & \multicolumn{1}{c|}{ Institutionalized Model } \\
\hline $\begin{array}{l}\text { Self-management } \\
\text { Attempts to create egalitarian, nonhierar- } \\
\text { chical structures } \\
\text { Consensus-based decision making }\end{array}$ & Clear division of labor and authority \\
\hline Continuity between means and goals & Means and goals loosely coupled \\
\hline $\begin{array}{l}\text { Alignment with external actors is unac- } \\
\text { ceptable }\end{array}$ & $\begin{array}{l}\text { Alignment with external actors is accepta- } \\
\text { ble }\end{array}$ \\
\hline Individual before the organization & Organization before the individual \\
\hline Creation of alternatives & Transformation through institutions \\
\hline
\end{tabular}

Yet, these actions present a dilemma and may be a source of controversies (see Katsiaficas 1977, 77) and internal conflict. An extreme example of the latter is a conflict about institutionalization in Spain, which culminated in 2009 when anti-institutionalist activists expressed their disapproval of attempts to achieve legalization of the squatted social center $\mathrm{Pa}$ tio Maravilla by means of a bomb attack.

Flesher Fominaya $(2007,339)$ noted that "in institutional politics, the individual exists for the organization and the individual is dispensable; in autonomous politics, organizations [...] exist to serve the desires and goals of the individuals participating in them, and are therefore dispensable." Part of the institutionalized model is a clear division of labor and authority and a tendency to seek transformation through existing institutions rather than through the creation of alternatives (Flesher Fominaya 2007).

We see the distinction between autonomous and institutionalized models as quite separate from the distinction between moderate and radical tendencies. Thus, a movement that is predominantly autonomous may be radical, but are not necessarily so. For example, a group's aim to create an alternative to the establishment does not imply the desire to overthrow the political system. In addition, an autonomous movement may have radical and moderate wings, as in the case of the squatters in Amsterdam described below.

A dual movement structure consists of self-contained social movements or SMOs that focus on the same issue or interest but are positioned on opposite sides of the autonomous - institutionalized spectrum. The term "movements" needs to be specified here. It refers to a narrow sense of the term that allows for more than one movement focusing on the same issue, not to the equally current use of the term as a conceptual container for all activism related to a given issue.

In a dual movement structure, the movements or SMOs develop separately which enables them to maximize their respective strengths. Instead of the term "dual movement 
structure" we could have proposed the metaphor of a body with wings, which more or less works when distinguishing radicals from moderates. However, for our purposes, such an image may result in the concept of "autonomous wing," which entails a contradiction in terms.

\section{Theory and case selection}

Our starting point is political opportunity theory. The current literature makes it quite clear that mobilization, shaping and success of social movements cannot be understood without considering the role of opportunities. Mobilization takes place in response to manifest opportunities, the structure of opportunities determines possible outcomes and the chance for success, and in contrast to earlier thinking on resource mobilization, movements cannot be deliberately created by determined entrepreneurs, even if they use sophisticated strategies (Tarrow 1994; McAdam 1995). This implies that a dynamic that combines the strengths of the autonomous and institutionalized models will normally not be created by design.

Opportunity theory holds that when opportunities are visible, expectations for success rise, encouraging collective action (Bröer and Duyvendak 2009; Koopmans and Muis 2009). Between opportunity and action, a lot happens that a deterministic model cannot capture (Goodwin and Jasper 1999). The political context provides a filtering process in which activists consider only actions that are consistent with perceived constraints (Kriesi 2007, 68). Established repertoires of action affect this filtering process as do frames designed to organize experience by simplifying and condensing aspects of "the world out there," to find resonance, and to guide action (Benford 2000).

Opportunity theory suggests at least one scenario in which a dynamic that combines the strengths of both models develops. A core variable is the openness of the political system, i.e. how easy or difficult it is for social movement actors to get access (Meyer, 2004). Some political systems are generally open, while other political systems are selectively open, i.e. there are gatekeepers who decide on the basis of the movements' demands whether a given movement will get access (cf. Kriesi et al. 1995). We can infer that such selectivity hinders autonomous movements in gaining access, because their framing is inherently inconsistent due to their decentralized structure and emphasis on individual expression. The corollary is that when the political system is selectively open, there can be niche opportunities to get access that require the unequivocal framing that only the institutionalized model can provide. This can be an impetus for activists to follow the institutionalized model.

The theoretical dual movement scenario assumes that there are also activists on the scene whose cultural preferences steer them in the direction of the autonomous model. This assumption seems reasonable, because since the 1960s, many activists feel more at home in a movement in which autonomy is part of a collective, countercultural identity (Melucci 1989; Polletta and Jasper 2001) and revel in self-organization, flexible commitments, and freedom from representative decision making. Even when the political opportunity structure is unfavorable to them, for instance when the political system is selectively open, movements that express an autonomous identity can still develop. This is because identity based movements are not very dependent on the political opportunity structure (cf. Kriesi et al. 1995; Kriesi 2007). Once there are separate movements or SMOs with different approaches, but focusing on the same issue or interest, they will create opportunities for each other (cf. Whittier 2007). 
We should allow for the possibility that the relationship of the movements' demand set to pre-existing ideas in the larger context conditions how the dynamic takes shape. In other words, this is the discursive opportunity structure which refers to the issues that a social movement is able to raise and to the viewpoints for which activists can expect resonance (Ferree 2003). The question is whether demands that are fundamentally at odds with the property relations of modern capitalism lead to different dynamics than demands that can be accommodated to liberalist ideologies. We can conceptualize this as the mainstreaming potential of the issue or interest at stake. When there is a great mainstreaming potential, activists can gain a lot by reaching out to as many people as possible, and this can stimulate cooperation between institutionalized and autonomous movements or SMOs.

These theoretical considerations motivated our case study design and case selection. We directed the research at issues/interests that could be studied in a context characterized by a generally open political system, as well as in conjunction with a political system that is selectively open to social movements. Therefore we studied urban squatting in the Netherlands, following Kriesi et al. (1995, 36-37) who describe the Dutch political system as characterized by "informal inclusion", and in the US. The latter choice reflects Tarrow's (1994: 90) assessment that the American state "presents an open door to groups which advance modest goals (..) but sets up a barricade against those who challenge property or security."

Because we wanted to explore the dynamic under different discursive conditions, we performed a theoretical replication (Yin 2009) by adding a second issue/interest, the fight against sexual violence. We deem the fight against sexual violence to have more mainstreaming potential than squatting. Squatting can provide low income housing, revive abandoned buildings, make unfunded cultural entrepreneurial projects possible and contribute to preservation efforts (Pruijt 2013b), but it is at odds with the role of private property in capitalism. The fight against sexual violence does not threaten central institutions, revolves around a widespread risk, resonates with a human right that is even more entrenched than the right to housing and is integral to notions of modernization.

For our case representing the fight against sexual violence combined with a political system that is generally open, we chose the Netherlands. For the case in which the political system is selectively open, we selected Spain. Spain is known as a country in which feminists had difficulty in getting access to the political system, unless they associated themselves as "double-militant feminists" (Colomer 2008; Threlfall 1996, Pereria 2003) with the social democratic party, Partido Socialista Obrero Español (PSOE) that led the government in 1982-1996 and 2004-2011. Table 2 summarizes the case selection.

Table 2. Case Selection

\begin{tabular}{l|l|l} 
& $\begin{array}{l}\text { Issue or interest has low } \\
\text { mainstreaming potential } \\
\text { (anti-systemic) }\end{array}$ & $\begin{array}{l}\text { Issue or interest has high } \\
\text { mainstreaming potential } \\
\text { (reform-oriented) }\end{array}$ \\
\hline $\begin{array}{l}\text { Political system generally } \\
\text { open }\end{array}$ & $\begin{array}{l}\text { Urban squatting in the } \\
\text { Netherlands }\end{array}$ & $\begin{array}{l}\text { The fight against sexual } \\
\text { violence in the Netherlands }\end{array}$ \\
\hline $\begin{array}{l}\text { Political system selectively } \\
\text { open }\end{array}$ & Urban squatting in the US & $\begin{array}{l}\text { The fight against sexual } \\
\text { violence in Spain }\end{array}$ \\
\hline
\end{tabular}

\section{Urban squatting}


For this study, we examined urban squatting-living in or otherwise using a dwelling without the owner's consent - in Amsterdam and in New York. In addition to consulting the extensive descriptive literature about the Amsterdam squatters' movement, this research included interviews, examination of archives, and systematic collection of documentation that the movement has produced. An important source of information was a complete set of periodicals that squatters published (Kraakkrant, 1976-1981, and its successors, Laatste Waarschuwing, 1981; Bluf! 1981-1988; NN, 1988-1995; and Ravage, 1996-2002). Participant observations in meetings occurred until 2012. We also studied squatting in New York using the descriptive literature, complemented by all news articles (278) on squatting in New York City that could be retrieved from the Lexis-Nexis database, background documents on housing policy in New York available online, and documents that squatters published on the Internet. Finally, our research included interviews with fourteen squatters, visits with three organizations related to squatting, examination of archives, and discussions with activists.

\section{Urban squatting in Amsterdam}

From its outset in 1963, squatting in Amsterdam entailed an autonomous movement, a decentralized network of informal groups (Pruijt 2003).

There was one brief episode that can be seen as an experiment to combine the strengths of both models. In 1969, activists, some of whom had previously been active in an anarchist group, Provo, that promoted squatting, started the Kabouter (gnome) movement with the aim to take part in local elections and to unite a wide range of society-changing initiatives, including squatting. The structure was a federation of autonomous groups, governed by a weekly open "Peoples Meeting" plus "interdepartmental" meetings of group representatives. The Kabouters used parody and irony to express their ambivalence towards the institutional aspects of their endeavor by presenting themselves as a state, Oranje Vrijstaat (Orange Free State), and by playing with a terminology derived from communist state bureaucracy. The autonomous squatting branch, for example, was called the "People's Department of Housing."

This People's Department of Housing, also known as Aktie '70, was successful in garnering resources and media attention, attracting volunteers and staging protests against evictions. In a famous prank, they took the Mayor's seat from the city council chambers and cut down its legs in a public event; later, it turned out to be a fake seat, the real one was found in a storage space in the town hall. By organizing a national squatting day they contributed to the diffusion of squatting. However, this productivity only lasted a short while. There was internal disagreement about whether or not to take part in the national election. The Kabouters in the city council were attacked for not listening to the People's Meeting, and they were also divided among themselves on the issue of direct vs. parliamentary action, and whether or not it was wise to demonstratively smoke pot in the council chambers. Leaders, most notably Roel van Duijn, became celebrities, which led to accusations of self-promotion from rank-and-file Kabouters. These internal conflicts led to Kabouter/Oranje Vrijstaat's collapse in 1971, after 18 months (Tasman 1996; Bogad 2005). The Kabouter experiment illustrates the difficulty of combining the strengths of the autonomous and institutionalized models in a single collectivity.

The closed thing to an institutionalized approach to squatting in Amsterdam involved alternative social service organizations designed to help people and change society at the same time. Some were subsidized, and facilitating squatting was part of their activities. In 1973, social service centers, including Streetcornerwork, founded the Kraakpandendienst 
(Squats Service) to cater for squatters in need of extra assistance. The Kraakpandendienst also aimed to involve homeless people and junkies in fixing up squats.

Meanwhile, the squatters' movement in Amsterdam continued to develop along the lines of the autonomous model. Although the movement was not devoid of hierarchy, there was an ideology of self-management (Wietsma, Vonk, and van der Burght 1982; Kadir 2010). Flexible teams, organizing from the bottom up, built up an infrastructure consisting of advisory services for aspiring squatters in several neighborhoods, telephone trees, squatters' media, bars and restaurants, theaters and concert halls, workshops, and a bureau that investigated real estate speculators (Duivenvoorden 2000). Squatting manuals emphasized that prospective squatters should be self-reliant and self-organizing. The autonomous model informed both the movement's radical segments that engaged in confrontations with the authorities, and the moderate groups that were busy creating artists' workspaces and businesses such as a theaters, restaurants, and shops.

Consistently, the political system was open for squatters. In 1973, four Kabouters combined the business opening up new squats with political work as city council members (Tasman 1996, 198). Starting in the late 1970s, direct talks between squatters and politicians were manifold in the context of the legalization of two hundred of the buildings that were occupied by squatters (Duivenvoorden 2000, 323).

The municipality also offered to make repairs to some of the squats that were slated for eventual demolition, to help keep the buildings habitable in the meantime. In many conflicts, for example in 1980 when squatters made street barricades in the Vondelstraat, politicians mediated. Squatters were accepted as participants in city planning dialogues, for instance in the east docklands. In 2010, squatters were able to mobilize politicians from the labor, green and liberal democratic parties against criminalization of squatting (Pruijt 2013a). Thus, the Dutch squatting case exemplifies the conditions present in the low-mainstreamingpotential / open-political-system box of Table 2. Autonomous activists encountered few restrictions when they tried to get access to the political system, there was no incentive to go the route of the institutionalized model.

\section{Urban squatting in New York City}

In contrast with Amsterdam, in New York an autonomous squatters' movement existed, but a significant institutionalized movement also emerged. To get a clear view of possible causes for this emergence, we split the examination of squatting in New York into two episodes: the 1970 squatting wave and that from 1978 onwards.

In 1970, the Upper West Side of Manhattan, then a working class area, was in the throes of urban renewal and the planned displacement of poor, predominantly immigrant families to make room for more upmarket housing. Scores of empty and still (partly) occupied buildings in the neighborhood were slated for demolition, while some families doubled or tripled up because they could not find an affordable apartment. These circumstances triggered a squatting wave that attracted a variety of people.

The first category consisted of political entrepreneurs who aimed to build powerful SMOs. A housing movement encompassing various SMOs sought to stop and reverse the displacement of low-income families, destruction of usable housing, poor maintenance, and warehousing of empty apartments. The city provided extra impetus to the mobilization because it failed to deliver on its promise to allow displaced tenants to return to the neighborhood. Squatting followed an incident in which a boy died from carbon monoxide poisoning linked to a boiler that the city had refused to fix, despite repeated pleas from the boy's mother. 
Activists mobilized families, including the family that had suffered the tragedy, to squat in thirty vacant apartments that were in better shape than those where the families normally lived. Muzio $(2009,121)$ described the action as "more spontaneous than part of a deliberately planned strategy of an organized movement." The action launched the organization Operation Move-In (OMI), which focused on squatting in city-owned buildings, including a storefront where it established its office. Increasingly, the movement developed in the direction of the institutionalized model. Police efforts to stop the occupations mandated a high level of coordination to ensure press photographers were present when smoothly operating teams opened up the apartments (Schwartz 1986).

A further turn towards the institutionalized model involved a motive that is not usually included as one of this model's strengths: the exclusion of potential participants. The squatter's movement attracted people from a wide variety of locations, against the preference of Puerto Rican group called El Comité, which joined OMI and sought to restrict squatters in apartments to residents or former residents from the neighborhood (Muzio 2009, 124). One of the El Comité organizers explained:

We decided we wanted to control the housing situation in a more organized fashion [...] We started planning which buildings should be taken over, which families should go here or there. We became more organized, rather than spontaneous. (Muzio 2009, 124).

An additional step towards the institutionalized model was alignment with a related but new goal: Activists in the fight against gentrification embraced squatting as a tactic to pressure urban planners to allocate a higher proportion of low-income housing to redevelopment sites (Muzio 2009). Schwartz $(1986,12)$ stated that these activists "tried to use the squatters as bargaining leverage"; in the end, some squatters were evicted, others legally allowed to stay.

The second category of people attracted to the squatting movement included students and other young people looking for a "summer project" (Brotherton 1978, 196). However, in neighboring Morningside Heights, the movement took less of a turn towards the institutionalized model. Here, a small team of five or six young men who lived, studied, or worked in the area, and who were interested in housing issues, organized squatting in buildings that were standing virtually empty because the owner and a nonprofit organization planned to build a facility for the elderly there. The activists recruited families from Operation Move-In's waiting list, and organized meetings, the actual squatting, legal assistance, and contacts with the media and supportive organizations. In this case, repression was not an urgent problem, since the developer was church-related and sensitive to normative pressure to avoid police action against poor families. Thus, this example suggests that a subtle difference in the opportunity structure can affect whether a movement develops in either the autonomous or the institutional direction.

The organizers planned to transfer leadership to the squatters, who continued to hang onto their buildings as a loosely self-organizing group, with their main collective project being "Plaza Caribe," a park they constructed themselves in a vacant lot (Brotherton 1978). In her ethnographic study, Brotherton $(1978,53)$ noted:

I soon discovered [...] that in spite of the squatting being done on Morningside Heights, there was no squatter organization there comparable to Operation Move-In in the urban renewal area. The Morningside Squatters were their own organization.

Compared to OMI, Morningside was a bold experiment because it entailed privately owned buildings. In 1979, the squatters won the title to the buildings, and the Episcopal Cathedral of St. John the Devine created the Urban Homesteading Assistance 
Board (UHAB) to assist them. UHAB supports self-management of buildings saved from abandonment.

"Hippies" were the third category of people drawn into the squatting movement (Muzio 2009). A group named "Local Storefront," a collective of activists running a "free, squatter store," sought "a collective life," according to their mission statement. The group made the strategic choice to bring people together through a food co-op and events such as film screenings, and they sought to inform neighborhood residents by publishing a newspaper, The Broadway Local, in which squatting was a prominent topic.

At this point, we can draw an interim conclusion. The 1970 squatting wave in New York shows how some differentiation in terms of the autonomous and institutionalized models may occur due to subtle differences in repression, exclusion of potential participants and activists' backgrounds and political agendas, as well as opportunities to influence decision making about the proportion of low-income housing on urban renewal sites. This differentiation enabled the field to attract a wide range of people, but beyond this, there was no indication of a dynamic that combined the strengths of the two models.

Around 1978, opportunities for gainful access to the political system opened up, giving rise to a strong institutionalized movement. The best example is the involvement of the Association of Community Organizations for Reform Now (ACORN), a formal organization with 75,000 members and branches in twenty-seven states. In 1985, ACORN organized squatting in twenty-five buildings in Brooklyn, enticing a state senator to participate in the action. The city originally had planned to auction off the buildings, but changed its policy after the squatting action and turned fifty-eight buildings over to ACORN/Mutual Housing Association of New York, which incorporated the squatters. Furthermore, the city provided funds for rehabilitation.

The backdrop was a crisis situation in which the City of New York, like other cities, faced an accumulation of thousands of abandoned buildings that had become city property because the owners had not paid their taxes. A widely promoted solution was urban homesteading: self-help housing in abandoned buildings and "sweat equity," the substitution of labor for money. Following experiments in several cities, a national framework for urban homesteading programs was enacted in 1974, in Section 810 of the Housing and Community Development Act (Borgos 1986). This act specified the conditions under which a public agency or a qualified community organization could receive funding as a local urban homesteading agency, which required selected potential homesteaders to be relatively poor but also able to repair properties. In addition, the act mandated homesteader agreements (eCFR 2012). Borgos $(1986,432)$ described official homesteading programs as a way to "tame" squatting.

However, the launch of the urban homesteading model, and the disappointment that followed when the bureaucracy blocked its widespread implementation, opened up opportunities for squatting. The ACORN action in Brooklyn was a continuation of those begun in 1979 in Philadelphia where ACORN launched a squatting campaign after lambasting the city council member in charge of homesteading for diverting buildings to speculators. ACORN's rules mimicked those established in the Housing and Community Development Act and required prospective squatters to sign a "squatters contract" (Borgos 1986).

Not only did this type of institutionalized squatting follow a state-created model, it also received some encouragement from officials. In 1978, a group named Banana Kelly in the South Bronx squatted in three buildings as a strategy to speed up an official homesteading project. A contact within the city administration suggested to the group that they might start clearing rubble from the buildings before the official permission came through (Brandes Gratz 1989). Some officials were weary of bureaucratic delays while suitable buildings were 
deteriorating. Jonnes (1980) quoted Philip St. George, an official at the city's Department of Housing Preservation and Development, as saying:

I've been an advocate of a squatters' zone in a place like the South Bronx.

Typically, people see squatters as evil, but they have a tremendous creative energy that would be good to harness in places like the South Bronx. Using their own labor and materials, they would be creating something for nothing. I can already hear the buildings code people howling, but when you have a situation like the South Bronx, these may be the only people who could pioneer it again.

However, the strategic partnerships with state actors were far from uniform. In several cities, ACORN's squatting actions met with repression (Borgos 1986).

The institutionalized movement created a legitimacy that affected the field of urban squatting in New York as a whole. The urban homesteading frame appealed to a wide range of home seekers and others because it focused not on deprivation but on renovation of abandoned buildings. Urban homesteading was interesting to people such as artists, who had low incomes but did not consider themselves deprived. However, some of them found themselves excluded from the institutionalized movement. Lower East Side artist and squatter Rolando Politi explained:

You were either "good" or "bad." "Good" if you had connections with the Lower East Side network of Catholic churches who had the leverage to deal with the city for turning over the properties to them and fit them in the official "Homesteading Program," and also "good" if you had access to local politicians who would somehow legalize you into the system under any obscure program they could come up with. (e-mail communication)

A further exclusionary aspect of official homesteading was that the city did not allow homesteaders to move into their buildings before all the work was finished, which could take years. This prohibition reduced risk because abandoned buildings often had no floors or stairs, or had leaking or partially missing roofs. At least one falling incident resulted in serious injury. Because of this policy, people who had nowhere else to live were excluded. Finally, the volume of institutionalized homesteading opportunities was minute compared with the number of people who needed cheap housing and the number of abandoned buildings.

On the Lower East Side of Manhattan, people, who did not fit into an institutionalized movement or whom institutionalized groups excluded, squatted anyway and began an autonomous squatters' movement. This movement provided cooperation and mutual help: There was an arrangement in which squatters worked together to help prevent evictions, although no formal organization was behind it. Residents moved from one squat to the next, and a general squatters' scene existed in the neighborhood (Ferguson 2007). The movement had no alignment with political or other organizations, as Frank Morales, a long-time New York and Lower East Side activist, explained:

As far as the left goes, we would often interact with various sectors of the left. Whether it's the housing movement or the political left, whoever that might be, from The Nation to various sectarian parties to the various leftist groups, and none of them wanted to deal with us, probably because we were autonomous. (quoted in Jaffe 2007, 202)

Lower East Side squatters were vocal in local debates on housing, demolition, gentrification and the way in which the city was treating homeless people and street peddlers. Van Kleunen $(1994,285)$ describes their input as "a chorus of voices" to which nobody listened. 
Squatting was the core of the autonomous movement's identity; it was simultaneously the end and the means, which helped to make squatting continuous. New squats were opened on the Lower East Side of Manhattan from 1983, when six buildings were taken over on Thirteenth Street until 1992 (713 East Ninth Street) (Ferguson, 2007). Twenty-five buildings had squatters. In 2002, a legalization process started for eleven buildings; in 2012, squatting in some buildings was legalized and the structures renovated, while others were still at the first stage of legalization. The authorities did not want to communicate with the squatters, therefore UHAB was called in as an intermediary.

While exclusion drove some squatters towards the autonomous model, it left them slightly marooned regarding their social identity. International diffusion solved this, and to some extent, the squatters' movement has become transnational. Self-labeling of squatters involves the use of the international squatters' sign, a circle crossed by a lightning-shaped arrow. Europeans, acting as movement brokers (McAdam et al. 2001), linked the New York and European squatters' scenes. An Italian artist, who left the anarchist scene in Berlin to move to New York, organized squatting in vacant apartments in three buildings on the Lower East Side in 1981. A British woman introduced New Yorkers to political ideas that were common among squatters in Europe. In 1988, a Dutch woman took the initiative to open up a large building in New York. Having been a squatter in the Netherlands, she tried, with partial success, to introduce the cooperative features that were common there, such as a squatters' bar, regular consultation and mutual support among buildings, a tool exchange, facilities for artists, and a theatre. In turn, American squatters visited European squatters' movements.

The institutionalized homesteading frame created dissonance for home seekers who were attracted to the idea but simultaneously excluded because of their social circumstances (cf. Walder 2009). This dissonance made a favorable reception of the European squatting frame possible. A Lower East Side squatter recalled:

We were still arguing about the use of the word squatting, and whether we should be squatters or homesteaders. Most people wanted to call it homesteading [...] But we weren't homesteaders. We didn't qualify for any of the [homesteading] programs, and most of those programs wouldn't want us anyway, even if we did [laughs]. Then English Steve and Cathy came and started using the term squatting left and right, and we kind of went with it from there. (Ferguson 2007, 151).

In addition, Michael Shenker noted, "We found a lot of reinforcement and encouragement through hearing what was going on in Europe. It helped to validate our analysis that this thing is possible, that it is real." (interview). Another activist reminisced, "I took to preaching the reformed gospel of the European Squatters with the irritating zeal of some television preacher." (Tolia 2007, 479)

To some extent, strife defined the movement trajectories on the Lower East Side when outside groups co-opted the institutionalized movement, which in turn elicited a negative reaction from the autonomous movement. Initially, autonomous squatters and those who embraced the official homesteading model tended to get along. The groups had communality because those following the homesteading model often started to work on buildings without permission - therefore, technically squatting — about a year ahead of officially entering the program (Van Kleunen 1994; Von Hassell 1996). Co-optation set in when at least one of the formal organizations that sponsored homesteading, the Lower East Side Catholic Area Conference (LESAC), joined a coalition that was negotiating a deal to build market-rate housing in the neighborhood. Under the plan, land would be sold for market-rate development to cross-subsidize renovation of low-income housing (Abu-Lugod 1994; Van Kleunen 1994). Autonomous squatters condemned this as a sellout that 
undermined the anti-gentrification struggle and labeled the nonprofit developers "poverty pimps" (Van Kleunen 1994).

This resentment was grounded in values, but it also was linked to a conflict of interest. Squatter Michael Shenker explained:

The great ideological conflict, the thing that distinguishes us from the local not-for-profits is that we wanted to develop and build our housing ourselves, manage our own affairs, develop our own collectives. We did not need to hire [or] pay salaries to absentee management. And as a result, the buildings that are still there more accurately reflect the personalities of the people that live in the building [...] than these other buildings. These buildings tend to be very institutional and reflect the culture of management [...]. We want to make our own choices. Nonprofits did not accept it, because in this way they don't make money. (interview)

The conflict of interest became insurmountable when nonprofit developers started to target buildings in which autonomous squatters had already created their homes (Van Kleunen 1994).

The autonomous movement acted as a strategic memory. For activists from the autonomous tradition, promoting the idea of squatting in a context where it is applicable but not part of the regular discourse, or where it has faded into the background, was an opportunity in itself. After gaining experience as an official homesteader and a squatter in the autonomous movement on the Lower East Side, Matthew Lee moved to the Bronx in 1987 where he started a neighborhood newspaper to promote squatting. He then organized a group named Inner City Press (ICP) / Community on the Move that squatted in twenty buildings. As an outgrowth of the autonomous squatters' movement on the Lower East Side, the Museum of Reclaimed Urban Space was created in 2012 in a legalized squat on the Lower East Side.

In 2011 and 2012, activists with a background in the autonomous movement on the Lower East Side played an important role in the collectives Organize for Occupation and Picture the Homeless with the aim of organizing people from the homeless shelter system to occupy of empty buildings (Picture the Homeless 2011).

Thus the second phase of squatting in New York, which started in 1978, can be seen as the emergence and development of a dual movement structure consisting of selfcontained movements that focus on the same issue or interest but are positioned on opposite sides of the autonomous - institutionalized spectrum. The impetus was the abandoned housing crisis which made officials look for a solution that involved partners in civil society.

The dynamic can be described as movements creating opportunities for each other. The autonomous movement pioneered squatting, while the institutionalized movement made the idea of taking over abandoned housing fashionable and created expectations that, in turn, fed the autonomous movement. Thus, the American squatting case exemplifies the conditions present in the low-mainstreaming-potential / selectively-open-political-system box of Table 2. While autonomous activists encountered substantial restrictions when they tried to get access to the political system, opportunities opened up that could only be used by institutionalized groups.

\section{The fight against sexual violence}


The location for our second field - resistance to sexual violence-was the Netherlands and Spain. In Amsterdam, we examined primary data such as reports, pamphlets, minutes, and communications on the various SMOs at the International Archives for the Women's Movement. In Spain, we consulted documents from personal and movement group archives. In addition, we interviewed at least two of the founding members of each group.

\section{The fight against sexual violence in the Netherlands}

The fight against sexual violence in the Netherlands was an autonomous movement - a decentralized network of informal groups - and sexual violence was an important issue in the women's movement around 1974. Taking inspiration from the UK, the group Blijf van m'n Lijf (Hands Off My Body), supported by a subsidized, alternative social service provider, opened the first shelter for battered women on the European continent in a secret location in Amsterdam, where they squatted in a former orphanage. They framed their action as a critique of existing social assistance practices that they described as paternalistic and patronizing (JAC 1975).

Groups in other cities also opened Blijf van m'n Lijf shelters. Within three years, increased demand caused financial strain on the movement. However, the shelter projects generated a positive resonance. Women's groups in left-wing parties proposed that the Dutch government subsidize the shelters. The State Secretary for Culture, Recreation, and Social Work visited the Amsterdam shelter, and subsidies came through. Nevertheless, Blijf van m'n Lijf chose to forgo political opportunities: The group refused to participate in an advisory committee on legislation concerning sexual behavior.

In the wake of subsidization, loss of autonomy loomed, which the activists tried to counteract. First, the state pressed shelters to ask for a larger financial contribution from their clients, which was possible because clients received welfare payments. Shelter groups protested because this clashed with the principle that their clients should be as self-sufficient as possible, but eventually most groups gave in. Then the government wanted to end the special status of the shelters and regulate them as any other kind of social service provider. Blijf van m'n Lijf lobbied to stall this. Next, the state moved to decentralize funding to the local level. Activists saw this as an attack on their autonomy, and two shelters closed their doors in protest. Notwithstanding such protests, professionalized shelters became a regular part of the institutionalized social service structure across the Netherlands (Meijnen 1994). The name Blijf van m'n Lijf remained in use in 2013, but was integrated into the regular (mental) health infrastructure.

In 1976, Vrouwen Tegen Verkrachting (Women Against Rape) established a rape crisis center that operated a telephone help line. This center was accessible for only a few hours per week, and in 1981, activists from Tegen Haar Wil (Against Her Will) applied for a subsidy for a 24/7 rape crisis center. The subsidy was granted with the provision that it would be temporary and that Tegen Haar Wil would transfer the activities to established, regular organizations.

Initially, the general mood in the movement was to keep a distance from the state, except in its role as a facilitator. However, the movement's message appealed to women who were active in Dutch left-wing political parties. They positioned themselves as allies and claimed attention from the government regarding the problem of sexual violence. These activities - and the fact that some of the movement's goals depended on state action for their realization-prompted the activists to seek political influence. Consequently, the state 
officially adopted the analysis that unequal power relations between men and women were the underlying problem (Dutch Department of Social Affairs, 1984). Rules were changed to allow divorcees easier access to housing; migrant women's dependency on their marriage for residence status was reduced; and no longer was marriage considered a special zone where rape could not legally exist. Some goals were not achieved, such as abolition of the distinction in the Dutch penal code between rape and sexual assault, for which Vrouwen tegen Sexueel Geweld (Women Against Sexual Violence) campaigned, and the denial to abusers the right to see their children.

When activists realized that allies in the left-wing parties did not support attempts to block an impending liberalization of pornography, they stepped up their radical actions against distributors (Van Mourik 1992). Some direct actions were taken against men suspected of rape. For example, in 1978 activists in Nijmegen marched with banners carrying the name of a rape suspect, although the court had thrown out the case. Another suspect discovered his car covered in syrup and feathers. Pornography distributors also were targets of disruptive actions (Van Mourik 1992).

In the late 1980s, Dutch policy began to lose its feminist characteristics, and feminists did not mobilize to counteract this change. New policy plans no longer framed violence against women as a gender issue - except for violence in ethnic minority communities - but categorized it under domestic violence, public health, and security. Subsidies for gender-specific activities were withdrawn (Outshoorn and Oldersma 2007).

The Dutch sexual violence case exemplifies the conditions present in the highmainstreaming-potential / open-political-system box of Table 2. Thus the autonomous movement could interact directly, and fruitfully, with Dutch politicians and an institutionalized movement did not even need to arise for significant gains to be realized. State actors took some ideas from the autonomous feminist movement and built these into welfare state arrangements. Counterfactual reasoning suggests a theoretical possibility that an institutionalized movement may have prevented activists from losing control over their creations.

\section{The fight against sexual violence in Spain}

In contrast to the Netherlands, in the Spanish case there was an autonomous plus an institutionalized movement. During the final years of dictatorship, autonomous feminist collectives were influential in Spain, but in the early years of democracy, there was a turn towards the institutionalized model (Castells 1997). The institutionalized movement consisted of double-militant feminists who opted for a double strategy: They situated their struggle within the political parties and within the women's movement. Double-militants stressed women's rights and strategically framed their vision and goals in terms of modernization and democratization, which coincided with the dominant political discourse (cf. Threlfall 1996).

This turn was a strategic choice to take advantage of opportunities offered by the powerful position of the social democratic party, PSOE, which won an absolute majority in parliament in 1982, and remained in power until 1996. Seeking to attract activists, the PSOE leadership offered feminists, who felt ideologically at home in the party, outstanding opportunities to leverage their ideas. Many feminists responded with enthusiasm, and those we interviewed recounted that they had been very optimistic about the chances for success and facilitation.

In 1982, feminists active in the PSOE, specifically in the group Mujer $y$ Socialismo, took part in the founding of the Commission to Investigate the Ill Treatment of Women (Comisión para la Investigación de Malos Tratos a Mujeres, CIMTM). CIMTM 
successfully lobbied for a state investigation of the problem. Their first public action was to push the Ministry of Internal Affairs to collect data on the incidence of violence against women (Gutiérrez Lopes 1990, 124). The minister responded rapidly with a special order directing the police force and the civil guard to register all cases of domestic violence and to report the data regularly (Gutiérrez Lopes 1990). Inspired by this success, CIMTM continued to lobby within the PSOE, more specifically among politicians and state officials, for extending to married women the same protective rights that unmarried women enjoyed. They claimed that democratization and modernization would be possible only if all citizens enjoyed the same protections of their freedom and integrity (CIMTM 1984).

The double-militant movement succeeded in placing the issue of domestic violence, malos tratos (abuse), on the political agenda, an achievement that was reached in the mid-1980s, mainly because of CIMTM's lobbying efforts. The Senate commissioned a special group to study the phenomenon. This group consulted women's organizations and experts, and published a report in 1989 based on international studies and policy documents (such as those from the European Union, Council of Europe, and United Nations). The report presented domestic violence as a structural problem related to women's economic dependency and cultural patterns, which confirmed CIMTM's analysis. The report stated that "patriarchal attitudes, in which everything that belongs to the realm of the family (women, children, and goods) falls under the authority of men, make it difficult to intervene" and "that there is a strong tendency in Spanish society to legitimate violence in the family sphere" (Comisión de Derechos Humanos del Senado 1989, 12183-12184). The report recommended soft law measures to prevent domestic violence such as consciousness-raising, a "know-yourrights" campaign, and police training.

The movement's double-militant strategy provided opportunities to secure funding because of the movement's good access to political power. In various cities, Associations for Aid to Raped Women (Associasión de Asistencia a Mujeres Violadas, AMV) were created. These organizations provided direct psychological, legal, and medical assistance to women who had been raped, and were involved in political action on behalf of victims. In 1986, the first AMV received financial support to establish a rape crisis center.

PSOE member Tina Alarcon and Christina Almeida, active in the political party Izquierda Unida, took the initiative to unite the AMVs into a federation. This federation, FAMUVI (Federación de Asociaciones de Asistencia a Mujeres Violadas), gave the organizations national status and access to funding generated from Spanish taxpayers, who individually can dedicate a .5 percent quota either to the Roman Catholic Church or to civil organizations.

One of the AMV federation's main concerns was the behavior of police and civil guard towards women who reported violence. Therefore, the AMV federation demanded that police officers undergo special training in how to treat female victims of violence. The AMV federation also insisted on the creation of specialized units to handle these issues within the police force. In response, the Ministry of Internal Affairs sent out several circulars ordering police to be alert and careful when dealing with violence against women. In May 1986, the minister created special police services for victims of sexual violence, the Servicios Atención a la Mujer. Also, the AMV federation was invited to deliver courses and seminars about violence against women to the police and civil guard (Gutierrez Lopez 1990, 129).

Castells (1997) noted that the feminist institutionalized movement in Spain brought a high level of success compared with other countries, especially the rise of women as political decision makers and the legal breakthroughs according to feminist demands; however, this success came at the expense of autonomy. Some Spanish feminists experienced institutionalization as a form of cooptation, which they resented: Some autonomous groups continued to dismiss as window-dressing the gains that double-militant feminists made 
(Cervera et al. 1992), and defined themselves as "anti-system." In the early 1980s, autonomous feminist groups in various parts of Spain launched autonomous shelter services, following the example of counterparts elsewhere in Europe. They visited shelters in the UK, France, Denmark, and Germany to learn from their experiences. Barcelona-based Grup Alba was the first group to visit the pioneer shelter Chiswick in the UK in 1981. Increasingly, shelter groups were able to get subsidies, especially from local authorities. In 1987, the shelters organized a network, the Coordinadora de Casas de Acogida (CCA), an autonomous organization that demanded central regulations and funding for shelters. However, the government did not respond to this petition, which provoked skepticism among many autonomous feminists about the role of the state. By the end of 1992, eighty-one shelters had been established across Spain (Instituto de la Mujer 1992, 92), and having a shelter for battered women became standard local social policy.

Also part of the autonomous movement was the feminist collective Comisión Anti-Agresiones (Commission Against [Sexual] Aggressions, CAA) that addressed the root causes of sexual violence. CAA groups did not offer services to victims of violence, and therefore, needed no funding. Instead, CAA adopted an anti-state ideology and discussed feminist theories about violence, which it combined with radical actions and manifestations to condemn concrete acts of violence.

The initial inspiration for CAA came from radical feminist groups in the US, which had developed since the early 1970s a strong movement in which rape was framed as the core mechanism of women's oppression. CAA discussed American theories on rape and sexuality and decided to combine this debate with concrete actions against violence. They organized marches to places where sexual assaults had taken place. The groups first adopted American ideas and slogans, but later criticized some of the ideas of their American counterparts. CAA wanted to avoid some of "the puritan tendencies" in the American discussion that defined (hetero) sexuality as the problem. Instead, they argued that Spain needed sexual liberation to break from its conservative, puritan past:

We should not leave sexuality for more secure times, but search for our pleasure now, and meanwhile, fight against the concrete forms of sexual violence (CAA 1988).

Opportunities for activism in the autonomous movement in Spain were less encouraging compared with those for the double-militant movement. Obtaining subsidies was more difficult for the autonomous shelter collectives than for the double-militant AMV. Autonomous shelter groups found themselves in the difficult situation of discursively gaining support from national and local authorities, but having no funding opportunities. The Comisión Anti-Agresiones de Gasteiz denounced this double discourse stating:

What is happening, we ask, when the institutions collect the demands long raised by the feminist movement, blur the goals and confuse public opinion, and pretend that they are doing what actually we are carrying out? (Gil 2011, 113).

Also, the Spanish autonomous movement found fewer opportunities compared with the Dutch autonomous movement. Dutch feminists who wanted to create a shelter did not have to worry about dealing with the state bureaucracy because they could squat in a building, but in Spain, the Grup Alba collective had to ask permission to use an abandoned building. Financial problems in the Netherlands also were less because of welfare payments.

Thus, the period 1982-1989 marked a heyday for strategic partnerships between Spanish state actors and social movements. A modernization process was under way that aligned with feminist values, the PSOE enjoyed the political majority position, and the 
partnership strategy seemed promising. As the double-militant movement prospered, the autonomous movement was marginalized.

However, opportunities for the autonomous movement began to change in 1989. The recommendations that the Senate committee had made as a result of lobbying by the double-militant CIMTM apparently were not leading to any concrete policy measures. Consequently, feminists questioned the strategy of investing in relationships with state actors, and placed mass mobilization on the agenda. Therefore, during the spring of 1989, the autonomous feminist collective Comisión Anti-Agresiones joined with the Coordinadora Estatal del Movimiento Feminista, which had assumed a coordinating role in the autonomous women's movement, to launch an intensive campaign to demand penal code reform (Comisión Anti-Agresiones 1989). An autonomous movement's pursuit of legal change may seem inconsistent, in terms of the typology of autonomous and institutionalized models; however, legal action is logical because creating an alternative will not stop perpetrators of sexual violence. Based on experiences of other European women's groups that struggled to improve legislation regarding domestic violence, these two groups presented a detailed proposal for new legislation (Valiente 1999). One central point in this proposal was to replace the existing legal definition that labeled sexual violence as "offences against purity" with a definition that framed sexual violence as an offence against the sexual freedom of women. The groups attracted left-wing opposition parties (IU, PCE, MC), trade unions (UGT and $\mathrm{CCOO}$ ), neighborhood associations, and student organizations to join them in a rally in Madrid.

In response to the campaign, the government proposed a legal reform in November 1989. The new code included malos tratos (abuse) as a crime, although the legal description remained rather vague and, for instance, did not include psychological violence. Repeated domestic violence (perpetrated at least three times) was punishable with imprisonment ranging from one to six months (Organic Act, No. 10 of 23 November 1989).

A factor in the autonomous groups' success was that they had a full capacity for mobilization and unconventional action, compared with the double-militant organizations, which were constrained by their alignment with the governing party.

However, feminist lawyers and legal scholars deemed the new law only a step in the right direction because it did not take into account the specific gendered nature of partner violence, and because they doubted whether the law would prove effective (Maqueda Abreu 2009). From 1991 onwards, women's organizations lobbied for better legislation. Yet, after the right-wing Partido Popular defeated the PSOE and took over the government in 1996, organizations with close ties to the PSOE, like the CIMTM, could no longer use their direct lobbying strategy, and started to use protest tactics similar to those of the autonomous groups. Feminist mobilization intensified after a dramatic event in December 1997. A victim of domestic violence, Ana Orantes, was killed by her former husband after appearing on a wellknown television show. Her murder caused public outcry , and according to Maqueda Abreu (2009), clearly illustrated the inadequacy of the existing legal framework. In reaction to the Orantes' murder, women's organizations massively mobilized to denounce violence against women (Osborne 2008). Both double-militants and autonomous organizations organized demonstrations and take-back-the-street marches (Gil 2011, 93). As a result, the media paid more attention to the issue of violence against women and the political parties in the opposition supported the movement's actions, which put pressure on the government (Medina Ariza 2002; Osborne 2008; Maqueda Abreu 2009). In April and June 1999, the government passed two legal reforms comprised of three modifications: 1) an expansion of the definition of domestic violence to include psychological violence; 2) inclusion of violence between cohabiting partners in the definition of domestic violence; and 3) new punishments for aggressors, such as a prohibition against approaching the victim (Maqueda Abreu 2009). 
However, women's organizations criticized the government's policy as mainly symbolic (Medina Ariza 2006). In January 2002, feminist organizations, united in a national feminist network against violence, mobilized to denounce the political parties' ability to effectively address the issue. After the PSOE's electoral victory in March 2004, the party executive prepared an integral law against violence. The Partido Popular also voted in favor of the new law, the 2004 Organic Law 1/2004, of 28 December, on Integral Protection Measures against Gender Violence (Ley Orgánica 1/2004, de Medidas de Protección Integral contra la Violencia de Género).

The law focused on the awareness, prevention, and early detection of gender violence, establishing a comprehensive range of multidisciplinary measures that included not only judicial and penal measures, but also a wide range of educational, healthcare, social, and assistance measures. The law defined gender inequality as the origin of men's violence against women, and considered men's violence against women as a form of gender-based discrimination, a political and structural problem requiring commitment from all public institutions. This gender specificity in the law, which was absent in the Dutch case, is evidence for the feminist influence.

The Spanish sexual violence case exemplifies the conditions present in the highmainstreaming-potential / selectively-open-political-system box of Table 2 . There were important opportunities for gainful access to the political system that only an institutionalized movement could take advantage of, which stimulated the rise of the institutionalized double militant movement. Nevertheless, the high mainstreaming potential of the issue precluded isolation of the autonomous movement and made it possible to forge a broad coalition that embraced the institutionalized and autonomous movements.

\section{Conclusions}

We have explored possible dynamics that combine the strengths of the autonomous and institutionalized social movement models, by examining movements that differ in terms of the mainstreaming potential of the issue that they focus on, and whether they face a political system that is generally open vs. selectively open. Four cases were selected that fit into the two-dimensional typology laid out in Table 2.

Urban squatting in the Netherlands is our case in the low-mainstreaming-potential / open-political-system box. It was autonomous at the start and the autonomous model remained dominant afterwards. In the 1970s, there were some attempts to design a dynamic that combines the strengths of the autonomous and institutionalized social movement models: the unstable and short-lived hybrid form created by the Kabouters in Amsterdam, and the institutionalized alternative assistance centers that embraced, promoted, supported and made use of autonomous squatting, also in Amsterdam. Autonomous activists enjoyed access to the political system, which they used in attempts to keep the authorities from interfering with squatting and to enlist their support for the legalization of squatted buildings. This seems to have helped the squatters to make the most out of the limited mainstreaming potential of squatting.

Our case in the high-mainstreaming-potential / open-political-system box is the fight against sexual violence in the Netherlands. Again, this involved an autonomous movement. This movement was able to directly influence state actors without the mediation of an institutionalized social movement. The high mainstreaming potential of the issue is apparent in how easy it was to mobilize politicians to take up the cause.

For the low-mainstreaming-potential / selectively-open-political-system box we selected the American squatting case. It is here that we see a dynamic, analogous to Staggenborg's (1989) observation, that entailed the interaction of self-contained movements 
or SMOs that are positioned on opposite sides of the autonomous - institutionalized spectrum, and which we termed a dual movement structure.

Synergy in this structure took the form of movements or SMOs creating opportunities for each other. In the US squatting case, there was an autonomous movement which pioneered squatting, while an institutionalized movement made the idea of taking over abandoned housing fashionable and created expectations that fed the autonomous movement. The autonomous movement showed a potential, due to the continuity of ends and means, to preserve a repertoire of disruptive action and act as a watchdog in case an institutionalized movement falls prey to a goal displacement from fighting for change to comfortable cooperation with the authorities (Tarrow 1994).

We argue that this dual movement structure came into being because niche opportunities for gainful access emerged, that required the clear framing associated with the institutionalized model. When in the US, the abandoned housing crisis erupted, prompting officials to turn to civil society for help, this gave the decisive impulse for a sharply institutionalized movement. In contrast, prior to this decisive development there were only some relatively subtle shifts in the direction of the institutionalized model, which could be explained as the effect of variations in repression and in activists' political agendas.

Notwithstanding the incentives to go the route of the institutionalized model, autonomous squatting continued to develop in New York. An explanation for this is that squatting fits to the expression of a collective identity that emphasizes a self-determined life (Pruijt 2013b). Autonomy is a matter of identity, and identity movements are not very sensitive to political opportunities (Kriesi 2007), which implies that they can function in a variety of contexts. Sub- or countercultural identities are diffused by activists who maintain international networks (Givan, Kolins, and Soule 2010; Tarrow 2010) and enter crucial ideas into the ongoing local dialogue (Chabot et al. 2010). An additional contextual factor in this case is that opportunities to participate in the institutionalized movement were limited.

To summarize, we see here that urban squatting in the US, facing a selectively open political system and with a low mainstreaming potential demand set, saw synergistic but not cooperative effects between the two types of movement.

The conditions present in the high-mainstreaming-potential / selectively-openpolitical-system box are exemplified in the Spanish case of the fight against sexual violence. In this case, a dual movement structure developed, just like in the US squatting case. The institutionalized "dual militant" movement created expectations that, in time, boosted the autonomous movement.

In Spain, autonomous activists found access to the political system blocked, except on the local level. Like in the US squatting case, we saw the rise of an institutionalized movement in response to niche opportunities for gainful access that required the clear framing associated with the institutionalized model. In the case of Spanish fight against sexual violence, the institutionalized movement got started when the PSOE chose to attract feminists in its quest to democratize and modernize the country.

The argument, outlined above, that identity based movements are not very sensitive to the political opportunity structure, can help explain the continued existence of the autonomous movement in Spain. An additional factor is that autonomous organization caters to the preference, noted by Ferree and McClurg Mueller $(2007,589)$ of women to 'organize outside the formal polity' because of the male dominance in state and state-related institutions.

In the case of the fight against sexual violence in Spain, eventually, cooperation between the movements developed. When the institutionalized double militant movement was affected by disappointing results of its lobbying strategy, the autonomous movement took the lead. When the PSOE, the party to which the double militant movement was linked, 
lost power, cooperation between the two movements proved to be the way forward. We argue that the mainstreaming potential of the fight against sexual violence provided an incentive for all those involved to reach out to as many people as possible. Thus in Spain, the high mainstreaming potential of the issue, but with only a selectively open political system, resulted in back and forth shifts between the autonomous and institutionalized movements as sequential centers of gravity, which led to the most cooperative synergistic example of a dual movement structure.

As we have seen in the Dutch cases, autonomous movements can be versatile. They can create synergy with state actors and thereby open up opportunities, even when the issue concerned has a low mainstreaming potential. When the issue has a high mainstreaming potential, cooperation with officials becomes possible. The condition that enables autonomous movements to be so versatile is that the political system is generally open. When, in contrast, it is only selectively open, as in the Spanish and American cases, niche opportunities can appear for institutionalized movements that interact with state actors. The result can be a synergistic dynamic between autonomous and institutionalized movements, that takes a cooperative form when the issue has a high mainstreaming potential.

\section{Acknowledgements}

We would like to thank six anonymous reviewers for their insightful, encouraging and helpful feedback, and Ángela García Bernardos and Sarah Diamant for supplying us with vital information. Irene van Oorschot, Sjaak Braster and Pascal Dérogée commented on an earlier version of the paper.

\section{Funding}

This research received no specific grant from any funding agency in the public, commercial, or nonprofit sectors. Some expenses were covered by the MOVOKEUR research project \#CSO2011-23079 ("The Squatters Movement in Spain and Europe: Contexts, Cycles, Identities and Institutionalization", Spanish Ministery of Science and Innovation".) 


\section{References}

Abu-Lughod, J. L. 1994. "Defending the Cross-subsidy Plan: The Tortoise Wins Again." In The Battle for Tompkins Square Park. From Urban Village to East Village. The Battle for New York's Lower East Side, edited by J. L. Abu-Lughod, 313-332. Oxford: Blackwell.

Benford, R. D. 2000. "Framing Processes and Social Movements: An Overview and Assessment. Annual Review of Sociology 26 (1): 611-639.

Bogad, L.M. 2005. Electoral Guerrilla Theatre. Radical ridicule and social movements. New York: Routledge

Borgos S. 1986. "Low-income Homeownership and the ACORN Squatters Campaign. In Critical Perspectives on Housing, edited by R. Bratt, C. Hartman, and A. Meyerson, 428446. Philadelphia: Temple University Press.

Brandes Gratz, R. 1989. The Living City: How America's Cities Are Being Revitalized by Thinking Small in a Big Way. New York: Simon and Schuster.

Breines, W. 1980. Community and Organization: The New Left and Michels' "Iron Law". Social Problems 27(4): 419-429.

Bröer, C. and J. W. Duyvendak. 2009. "Discursive Opportunities, Feeling Rules, and the Rise of Protests Against Aircraft Noise. Mobilization 14 (3): 337-356.

Brotherton, M. A. 1978. Conflict of Interest, Law Enforcement, and Social Change: A Case Study of Squatters on Morningside Heights. Ann Arbor: University Microfilms International.

CAA (Comisión Anti-Agresiones). 1988. Jornadas Anti-Agresiones. Madrid: Archivo CAA Madrid.

CAA, Comisión AntiAgresiones, (1989). Ante la violación: Responde. Reforma del Código Penal ;Ya! (CAA leaflet).

Castells, M. 1997. The Power of Identity. Malden, MA: Blackwell.

Cervera, M. M. Morón, C. Pérez, J. Pinto, and E. Srafeig. 1992. "Reflexiones Sobre el Movimienta Feminista de los Años 80-90." Mientras Tanto, 48: 33-49.

Chabot S., R. K. Givan, K. M. Kolins, and S. A. Soule. 2010. "Dialogue Matters. Beyond the Transmission Model of Transnational Diffusion between Social Movements." In The Diffusion of Social Movements: Actors, Mechanisms, and Political Effects, edited by R. K. Givan, K. M. Kolins, and S. A. Soule, 99-124. Cambridge: Cambridge University Press.

CIMTM (Comisión Para la Investigación de Malos Tratos a Mujeres). 1984. Documento de Análisis. Madrid: CIMTM.

Comisión de Derechos Humanos del Senado. 1989. Ponencia de Investigación de Malos Tratos a las Mujeres [Research Report on Ill-Treatment of Women], en BOGG. Senado III Legislatura. Serie I. Boletín General, 12 de mayo de 1989, 313. 
Colomer, J. 1996. Spain and Portugal: Rule by Party Leadership. In: Colomer J (ed) Comparative European Politics. Abingdon: Routledge, pp. 174-207 [third edition]

Duivenvoorden, E. 2000. Een Voet Tussen de Deur. Geschiedenis van de Kraakbeweging 1964-1999. Amsterdam: Arbeiderspers.

Dutch Department of Social Affairs. 1984. Bestrijding van seksueel geweld tegen vrouwen en meisjes [Combating sexual violence against women and girls]. HTK 18542, nr. 2.

e-CFR. 2012. Title 24: Housing and Urban Development, Part 590-Urban Homesteading. http://ecfr.gpoaccess.gov.

Ferguson, S. 2007. "The Struggle for Space-Ten Years of Turf-battling on the Lower East Side." In Resistance: A Radical Political History of the Lower East Side, edited by C. Patterson, J. Flood, and A. Moore, 141-165. New York: Seven Stories Press.

Ferree, M. 2003. Resonance and radicalism: Feminist framing in the abortion debates of the United States and Germany. American Journal of Sociology 109(2): 304-44.

Ferree M. and C.M. Mueller 2007 "Feminism and the Women's Movement: A Global Perspective". In The Blackwell Companion to Social Movements, edited by D. A. Snow, S. A. Soule, and H. Kriesi, 576-607. Malden, MA: Blackwell.

Flesher Fominaya, C. 2007. “Autonomous Movements and the Institutional Left: Two Approaches in Tension in Madrid's Anti-globalization Network. South European Society and Politics (12) 3: 335-358.

Gil, S. L. 2011. Nuevos Feminismos. Sentidos Comunes en la Dispersión. Una Historia de Trayectorias y Rupturas en el Estado Español. Madrid: Traficantes de Sueños.

Givan, R. K., K. M. Kolins, and S. A. Soule. 2010. "Introduction. The Dimension of Diffusion. In The Diffusion of Social Movements: Actors, Mechanisms, and Political Effects, edited by R. K. Givan, K. M. Kolins, and S. A. Soule, 1-15. Cambridge: Cambridge University Press.

Goodwin, J. and J. M. Jasper. 1999. "Caught in a Winding, Snarling Vine: The Structural Bias of Political Process Theory." Sociological Forum 14 (1): 27-54.

Gutiérrez Lopez, P. 1990. "Violencia Domestica. Respuesta Legal e Institucional.” In Violencia y Sociedad Patriarcal, edited by V. Marquiera and C. Sanchez, 123-136. Madrid: Pablo Iglesias.

Instituto de la Mujer. 1992. Memoria 1992 [Annual Report 1992]. Madrid: Instituto de la Mujer.

JAC (Jongeren Advies Centrum). 1975. Jaarverslag. Amsterdam: JAC.

Jaffe, A. 2007. "Frank Morales." In Resistance: A Radical Political History of the Lower East Side, edited by C. Patterson, J. Flood, and A. Moore, 193-212. New York: Seven Stories Press.

Jonnes, J. 1980. "For Squatters, Rent-free Life Is the Solution to High Costs." New York Times, March 23, R1. 
Kadir, N (2015). The Autonomous Life? Paradoxes of Hierarchy and Authority in the Squatters Movement in Amsterdam. New York: Bloomsbury Academic (forthcoming)

Katsiaficas, G. 1997. The Subversion of Politics: European Autonomous Social Movements and the Decolonization of Everyday Life. Atlantic Highlands, NJ: Humanities Press.

Koopmans, R. 2007. "Protest in Time and Space: The Evolution of Waves of Contention." In The Blackwell Companion to Social Movements, edited by D. A. Snow, S. A. Soule, and H. Kriesi, 19-46. Malden, MA: Blackwell.

Koopmans, R., and J. Muis. 2009. "The Rise of Right-wing Populist Pim Fortuyn in the Netherlands: A Discursive Opportunity Approach.” European Journal of Political Research 48 (5): 642-664.

Kriesi, H. 2007. "Political Context and Opportunity." In The Blackwell Companion to Social Movements, edited by D. A. Snow, S. A. Soule, and H. Kriesi, 67-90. Malden, MA: Blackwell.

Kriesi, H., R. Koopmans, J. W. Duyvendak, and M. Guigni. 1995. New Social Movements in Western Europe. A Comparative Analysis. London: UCL Press.

Maqueda Abreu, M. 2009. “1989-2009: Veinte Años de 'Desencuentros' Entre la Ley Penal y la Realidad de la Violencia en la Pareja [Twenty years of incongruence against the penal code and the reality of partner violence]. REDUR 7, 25-35.

McAdam, D. 1995. "'Initiator' and 'Spin-off' Movements: Diffusion Processes in Protest Cycles." Paper presented at the Conference on Cross-National Influences and Social Movement Research, Mont-Pelerin, Switzerland, June 15-19.

McAdam, D., S. Tarrow, and C. and Tilly. 2001. Dynamics of Contention. Cambridge: Cambridge University Press.

Medina Ariza, J. J. 2002. Violencia Contra la Mujer en la Pareja: Investigación Comparada y Situación en España [Intimate Partner Violence: Comparative Research and Situation in Spain]. Valencia, Spain: Tiranc lo Blanc.

Medina-Ariza, J. 2006. Politics of crime in Spain, 1978-2004. Punishment and Society, 8(2), 183-201.

Meijnen, A. 1994. "Blijf Gebleven.” In Het Klappen van de Zweep: 20 Jaar Blijf van M'n Lijf Amsterdam, edited by J. De Lima, 20. Amsterdam: Jan van Arkel.

Melucci, A. 1989. Nomads of the Present: Social Movements and Individual Needs in Contemporary Society. London: Hutchinson Radius.

Meyer, D. S. 2004. Protest and Political Opportunities. Annual review of sociology 30: 125145.

Muzio, R. 2009. “The Struggle Against 'Urban Renewal' in Manhattan's Upper West Side and the Emergence of El Comité." Centro Journal (XXI) 2: 109-141.

http://www.redalyc.org/pdf/377/37720842006.pdf.

Offe, C. 1985. "New Social Movements: Challenging the Boundaries of Institutional Politics." Social Research 52 (4): 817-868. 
Osborne, R. 2008. "De la «Violencia» (de Género) a las «Cifras de la Violencia»: Una Cuestión Política." Revista de Metodología de Ciencias Sociales, Universidad Nacional de Educación a Distancia 15, 99-124.

Outshoorn, J., and J. Oldersma. 2007. "Dutch Decay: The Dismantling of the Women's Policy Network in the Netherlands." In Changing State Feminism, edited by J. Outshoorn and J. Kantola, 182-202. Houndmills, UK: Palgrave.

Pereria, A. P. 2003. "Women's Political Organizations in the Transition to Democracy: An Assessment of the Spanish and Italian Cases." Journal of Women's History (15) 3: 143147.

Picture the Homeless. 2011. Banking on Vacancy. Homelessness and Real Estate Speculation. New York: Picture the Homeless.

Piven, F. F., and R. A. Cloward. 1977. Poor People's Movements. Why They Succeed, How They Fail. New York: Pantheon Books.

Polletta, F., and J. M. Jasper. 2001. "Collective Identity and Social Movements." Annual Review of Sociology 27 (1): 283-305.

Pruijt, H. 2003. "Is the Institutionalization of Urban Movements Inevitable? A Comparison of the Opportunities for Sustained Squatting in New York City and Amsterdam." International Journal of Urban and Regional Research 27 (1): 133-157.

Pruijt, H. 2013a. Culture Wars, Revanchism, Moral Panics and the Creative City. A Reconstruction of a Decline of Tolerant Public Policy: The Case of Dutch Anti-squatting Legislation. Urban Studies, 50(6), 1114-1129

Pruijt, H. 2013b. The Logic of Urban Squatting. International Journal of Urban and Regional Research 37 (1): 19-45.

Schwartz, J. 1986. “Tenant Power in the Liberal City, 1943-1971." In The Tenant Movement in New York City, 1904-1984, edited by R. Lawson and M. Naison, 134-208. New Brunswick, NJ: Rutgers University Press. www.tenant.net.

Scott, W. R., and G. F. Davis. 2007. Organizations and Organizing. Rational, Natural, and Open Systems Perspectives. Upper Saddle River, NJ: Pearson Education / Prentice Hall.

Staggenborg, S. 1989. Stability and Innovation in the Women's Movement: A Comparison of Two Movement Organizations. Social Problems 36(1): 75-92.

Tarrow, S. 1994. Power in Movement, Social Movements and Contentious Politics. Cambridge: Cambridge University Press.

Tarrow, S. 2010. "Dynamics of Diffusion. Mechanisms, Institutions, and Scale Shift.” In The Diffusion of Social Movements: Actors, Mechanisms, and Political Effects, edited by R. K. Givan, K. M. Kolins, and S. A. Soule, 204-219. Cambridge: Cambridge University Press.

Tasman, C. 1996. Louter Kabouter. Kroniek van een Beweging. 1969-1974. Amsterdam: Babylon-De Geus. 
Threlfall, M. 1996. "Feminist Politics and Social Change in Spain." In Mapping the Women's Movement, edited by M. Threlfall, 115-151. Boulder/Oxford: Westview Press.

Tolia, K. 2007. “Activism by an Activist.” In Resistance: A Radical Political History of the Lower East Side, edited by C. Patterson, J. Flood, and A. Moore, 478-482. New York: Seven Stories Press.

Valiente, C. 1995. "The Power of Persuasion. The Instituto de la Mujer in Spain.” In Comparative State Feminism, edited by D. McBride Stetson and A. Mazur, 221-236. London: Sage.

Valiente, C. 1999. But where are the men? Central-state public policies to combat violence against women in post-authoritarian Spain (1975-1999). Paper presented at the Council of Europe Seminar on Men and Violence Against Women, Strasbourg, France.

Van Kleunen, A. 1994. “The Squatters: A Chorus of Voices ... But Is Anyone Listening?” In From Urban Village to East Village: The Battle for New York's Lower East Side, edited by J. L. Abu-Lughod, 285-312. Oxford, UK: Blackwell.

Van Mourik, I. 1992. “Wegens Vrouwenhaat Gesloten': De Strijd Tegen Porno.” In Heksennacht. Feministische Visies op Pornografie, edited by L. Lederer, 25-58. Amsterdam: SARA.

Von Hassell, M. 1996. Homesteading in New York City, 1978-1993. The Divided Heart of Loisaida. Westport, CT: Bergin \& Garvey.

Walder, A. G. 2009. "Political Sociology and Social Movements." Annual Review of Sociology 35 (1): 393-412.

Whittier N (2007) The Consequences of Social Movements for Each Other. In: Snow DA, Soule SA and Kriesi H (eds) The Blackwell Companion to Social Movements. Malden: Blackwell, 531-552

Wietsma, A., J. Vonk, J., and F. van der Burght. 1982. Als Je Leven Je Lief Is. Vraaggesprekken met Krakers en Kraaksters. Amsterdam: Lont.

Yin, R. 2009. Case Study Research: Design and Methods. London, Sage. 